\title{
Analysis of Interleukin-10 Anti-inflammatory Cytokines in Salivary Lymphocyte Surface: A cross Sectional Study
}

\author{
Retno Indrawati', Muhammad Luthfi', Aqsa S. Oki' ${ }^{1}$, Yuliati', Agung Sosiawan'2, Priyawan Rachmadi ${ }^{3}$, Muhaimin Rifai ${ }^{4}$ \\ ${ }^{1}$ Department of Oral Biology, Faculty of Dental Medicine, Universitas Airlangga, Surabaya, Indonesia, ${ }^{2}$ Department of Dental Public Health, Faculty of Dental Medicine, \\ Universitas Airlangga, Surabaya, Indonesia, ${ }^{3}$ Department of Dental Material, Faculty of Dental Medicine, Universitas Airlangga, Surabaya, Indonesia, ${ }^{4}$ Department of \\ Physiology, Cell Culture and Animal Development, Faculty of Science, Universitas Brawijaya, Malang, Indonesia
}

\section{Abstract}

Aim: To analyze the expression of interleukin-10 (IL-10) in children with severe early childhood caries (S-ECC) and caries-free children. Materials and Methods: This was an observational analytic pilot study performed on children with social factors-ECC (S-ECC), and caries-free children as the objects of research with a cross-sectional study design. Saliva of children aged 4-6 years from the group of caries children in severe and caries-free early childhood was taken. Samples were taken by rinsing with $1.5 \%$ sterile $\mathrm{NaCl}$ for $30 \mathrm{~s}$ and then accommodated in a sterile tube, to get a $40 \mathrm{~mL}$ sample from the aforementioned procedure repeated four times. Flow-cytometry test was used to analyze the IL-10 expression. The results of the study were analyzed using the normality test using Shapiro-Wilk, then continued with $t$ test using the Statistical Package for the Social Sciences (SPSS) software program, version 20.0 (IBM Corp., Armonk, NY, USA). The data were analyzed by independent $t$ test to see the difference between cariesfree children and S-ECC. Results: The expression of IL-10 in the saliva of children with severe ECC was 3.32 \pm 0.79 ; meanwhile, in caries-free children it was $4.04 \pm 0.65$. Conclusion: The IL-10 expression in children with severe ECC was significantly lower than that of in caries-free children.

Keywords: Interleukin-10 Anti-inflammatory Cytokines, Lymphocyte Cells, Severe Early Childhood Caries

Received: 20-11-2018, Revised: 29-02-2020, Accepted: 04-03-2020, Published: 21-10-2020.

\section{INTRODUCTION}

Dental caries is a multifactorial disease due to various factors, namely cariogenic microbes, carbohydrates, and social factors, whereas early childhood caries (ECC) is often found in children with low-socioeconomic conditions. ${ }^{[1]}$ Several studies have recognized the importance of infection of Streptococci mutans. ${ }^{[2]}$

The immune system is a very varied compilation of cells, consisting of two parts of the immune system, namely innate and adaptive. The innate and adaptive immune systems are interrelated, and recognition by innate immune systems can cause the activation of the adaptive immune response. ${ }^{[3]}$ The innate immune system is the first line of host defense against pathogens and recognizes molecules repeatedly against pathogens, which are called pathogen-related molecular

\begin{tabular}{|l|l|}
\hline \multicolumn{2}{|c|}{ Access this article online } \\
\hline Quick Response Code: & Website: \\
\hline & www.jioh.org \\
\hline & \\
\hline
\end{tabular}

patterns through germline-encoded pattern recognition receptors (PRRs) such as toll-like receptors (TLRs). ${ }^{[4]}$

The components that regulate the immune system, such as an immune regulator cells and regulating cytokines, both natural and acquired as induced by an antigen, plays an important role in controlling various immune responses, both physiological and pathological. Local and systemic interleukin-10 (IL-10) responses have been shown to have pathophysiological relevance in several diseases such as malignancy, infectious diseases, autoimmune diseases, and atopic disorders. ${ }^{[5]}$ Because of

\section{Address for correspondence: Dr. Muhammad Luthfi, Jl. Prof. Dr. Moestopo, No. 47, Surabaya 60132, Jawa Timur, Indonesia. E-mail:m.luthfi@fkg.unair.ac.id}

This is an open access journal, and articles are distributed under the terms of the Creative Commons Attribution-NonCommercial-ShareAlike 4.0 License, which allows others to remix, tweak, and build upon the work non-commercially, as long as appropriate credit is given and the new creations are licensed under the identical terms.

For reprints contact: reprints@medknow.com

How to cite this article: Indrawati R, Luthfi M, Oki AS, Yuliati, Sosiawan A, Rachmadi P, et al. Analysis of interleukin-10 antiinflammatory cytokines in salivary lymphocyte surface: A cross sectional study. J Int Oral Health 2020;12:439-42. 
this, IL-10 can activate signal transducer and activator of transcription 3 (STAT3) in macrophages and T cells to restore and respond to the presence of pro-inflammatory cytokines. ${ }^{[6]}$

Immunity in the oral cavity's immune system has an important role that is balancing the amount of microbes in the mouth. The microbial activity in oral cavity can be fluctuatives, due to pathogen situations. The mouth is the entrance and exchange with the outside environment. Therefore, homeostasis factors must be evaluated and controlled by the immune system. The immune response to pathogens involves the rapid activation of the secretion of pro-inflammatory cytokine, which functions to initiate host defenses against microbial invasion. However, excessive inflammatory cytokines in the tissues can cause systemic metabolic and hemodynamic disorders that are harmful to the host. As a result, the immune system has evolved to form anti-inflammatory functions to suppress the production of pro-inflammatory cytokines that function to limit tissue damage and to maintain tissue homeostasis. ${ }^{[7]}$ IL-10 is an anti-inflammatory cytokine that plays an important role in preventing prolonged inflammation. ${ }^{[8]}$

For dental caries preventions, many efforts had been carries out. The government and supporting health organization ran some prevention programs, such as dental counseling to community. Most of the programs targeted children, pregnant woman, and elderly. They teach how to brush teeth properly, dietary that good for dental health, prevention treatment that can be applied for children, and vaccines. ${ }^{[9]}$ Therefore, this study aimed to analyze the expression of IL-10 in saliva which functions as an anti-inflammatory. The results of this study are expected to be used as a marker of social factors-ECC (S-ECC).

\section{Materials and Methods}

This was an observational analytic study using children with S-ECC and caries-free children as the objects of research with a cross-sectional study design. Ethical clearance test at Faculty of Dental Medicine, Universitas Airlangga, Indonesia was performed with Health Research Ethical Clearance Commission (approval number 209/ HRECC.FODM/IX/2017).

Sixteen children with S-ECC and caries-free were taken from preschool children aged 4-6 years, in the southern

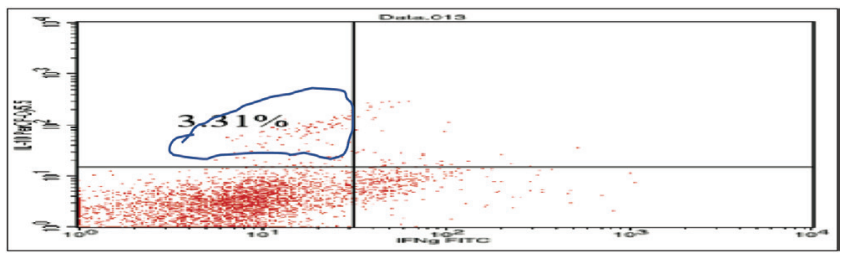

Figure 1: Expression of interleukin-10 (3.31\%) from severe early childhood caries salivary after analyzed by flow-cytometry test
Surabaya region, which had previously been divided into two groups.

Group one were children with a diagnosis of S-ECC characterized by decay, extraction, and filling (def- $t>6$ ), whereas, the second group were preschool children who were diagnosed with free caries marked with def- $t=0$.

$5 \mathrm{~mL}$ saliva is taken from preschool children with S-ECC and caries free. Sampling was carried out by researchers and trained research assistants using standard protocols. Subjects were asked not to consume food and drink, or brush their teeth for $60 \mathrm{~min}$ before the study was conducted. The samples obtained were stored at $-80^{\circ} \mathrm{C}$ for analysis. IL-10 expression was analyzed using flow cytometry, according to Luthfi et al. ${ }^{[10]}$

Statistical analysis: The data were analyzed by independent $t$ test to see the difference between caries free and S-ECC.

\section{RESULTS}

Data from the results of the study before analysis using the $t$ test, conducted tests of normality and homogeneity using the SPSS Shapiro-Wilk test. The results of this test showed a value of $P>0.05$, which means that all data were normally distributed and homogeneous. Normality test using Shapiro-Wilk data showed normal distribution, whereas Levene test results showed homogeneous data.

The data obtained indicate that the average IL-10 in the caries-free group was higher than the S-ECC group, but the difference was not statistically significant between caries-free and S-ECC.

\section{Discussion}

From the data obtained from the research results then performed statistical calculations. Before testing and analysis between S-ECC groups and caries free, the normality test was done in each group using the ShapiroWilk test which obtained the result that the value of $p$ $>\alpha=0.05$ is $\mathrm{P}=0.844$ which means that the data are normally distributed, as shown in Tables 1 and 2 is the result of statistical analysis between S-ECC and caries free using independent $t$ test, the value of $\mathrm{p}=0.11$ means that there are differences in expression even though statistically it is not showed significant results because the value of

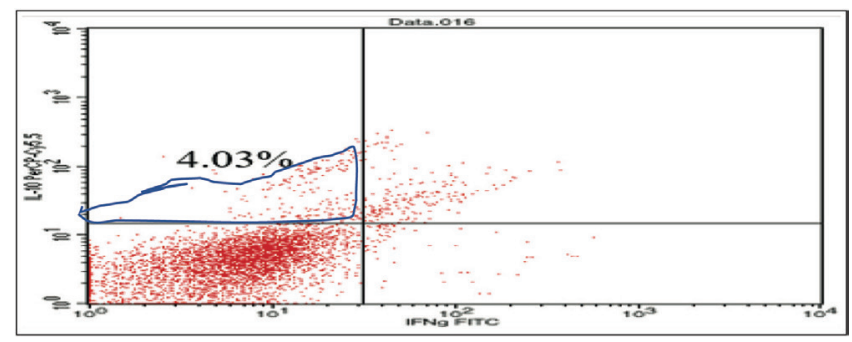

Figure 2: Expression of interleukin-10 (4.03\%) from caries free salivary after analyzed by flow-cytometry test 
Luthfi, et al: IL-10 cytokines expression in saliva of caries

\begin{tabular}{|c|c|c|c|c|c|c|}
\hline Variable & & ov-S & & & ro-U & \\
\hline \multirow[t]{2}{*}{ IL-10 } & Statistic & $\mathrm{Df}$ & Sig. & Statistic & $\mathrm{Df}$ & Sig. \\
\hline & 143 & 16 & 200 & 970 & 16 & 844 \\
\hline
\end{tabular}

Table 2: Mean and standard deviation of interleukin-10 expression in severe early childhood caries and caries free analyzed by flow-cytometry test, which was tested using independent $t$ test

\begin{tabular}{|c|c|c|c|}
\hline \multirow[t]{2}{*}{ Group } & \multirow[t]{2}{*}{$n$} & \multicolumn{2}{|c|}{ IL-10 expression (\%) } \\
\hline & & Mean \pm SD & $P$ \\
\hline Caries free & 8 & $4.04 \pm 0.89$ & 0.11 \\
\hline S-ECC & 8 & $3.32 \pm 0.76$ & \\
\hline
\end{tabular}

$\mathrm{S}-\mathrm{ECC}=$ severe early childhood caries, $\mathrm{SD}=$ standard deviation, $\mathrm{IL}-10=$ interleukin-10

$\mathrm{p}>0.05$. on the surface of lymphocyte cells in saliva the S-ECC group that expressed IL-10 (3.31\%) was less than that of the caries free group that expressed IL-10 (4.03\%) this will be clarified in Figures 1 and 2.

Based on Figure 1 which is the result of examination using flow cytometry test shows that lymphocytes in saliva severe early childhood caries express IL-10 of 3.31\%, while in Figure 2 which is the result of examination using flow cytometry test shows that lymphocytes in cariesfree children express IL-10 at $4.03 \%$. This shows that the S-ECC saliva is less specialized in proinflammatory cytokines and conversely expresses inflammatory cytokines which results in chronic inflammation. The occurrence of chronic inflammation is caused because innate immunity in S-ECC is not as good as in free caries so innate immunity is not able to fight the pathogens that cause dental caries.

IL-10 is an anti-inflammatory cytokine produced by innate immunity secreted because of the response of pathogen recognition receptors (PRRs) in contact with pathogenassociated molecular patterns (PAMPs). Secretion of IL-10 during bacterial infection is the most important factor in resolution of infection. ECC has an impact on general health, ranging from local pain, infections, and abscesses.

The results showed the occurrence of decreased IL-10 expression in preschool children with S-ECC compared with in caries-free children. This may be preschool children with S-ECC responding to more antigens in the form of $S$. mutans bacteria, which are relatively high in number compared to children with free caries. ${ }^{[1]}$

Antigen structures called PAMPs, which will be recognized by PRRs, namely TLRs, are very important to trigger the effect or phase of the innate immune response. ${ }^{[12]}$ TLR2 and TLR4 involved in the introduction of gram-positive and gram-negative bacteria that have been detected in the odontoblast cell membrane in healthy pulp show that odontoblasts are equipped to recognize these pathogens when they diffuse through dentinal tubules during carious infection. ${ }^{[13]}$
One of the main consequences of TLR activation is an increase in innate immune efficacy, including antimicrobial and cytokine agents and pro-inflammatory chemokines that recruit and activate immune cells. ${ }^{[14]}$ One of the main consequences of TLR activation is an increase in the effectiveness of innate immunity, including antimicrobial and cytokine agents and pro-inflammatory chemokines that recruit and activate immune cells. ${ }^{[14]}$ This causes a prolonged increase in inflammatory cytokines in S-ECC, increasing IFN- $\gamma$ increase expression. ${ }^{[15]}$ which can ultimately cause oral cavity tissue damage that affects general health, ranging from local pain, infections, abscesses, difficulty chewing, malnutrition, indigestion, and trouble sleeping. ${ }^{[16]}$

Study shows that an increase in pro-inflammatory cytokines occurs in S-ECC; this must be balanced by the host immune system by producing anti-inflammatory cytokines, IL-10. Cluster differentiation $4\left(\mathrm{CD}^{+}\right)$memory $\mathrm{T}$ cells are developed in response to pathogenic microbes. $\mathrm{CD} 4^{+}$ memory $\mathrm{T}$ cells prevent the body from fighting pathogens. ${ }^{[17]}$ $\mathrm{CD}^{+}$cells also respond as antipathogens, ${ }^{[18]}$ which produce antibodies and cytotoxicity of cluster differentiation 8 $\left(\mathrm{CD}^{+}\right) \mathrm{T}$ cells, ${ }^{[19]}$ but this does not occur in S-ECC so IL-10 expression in S-ECC saliva is lower than in caries-free children. This study requires larger sample size to evaluate the expression in different age groups and populations.

\section{ConcLusion}

IL-10 expression in salivary lymphocytes of children with $\mathrm{S}-\mathrm{ECC}$ is lower than that of caries-free children.

\section{Acknowledgement}

The authors would like to Research Centre Faculty of Dental Medicine Universitas Airlangga.

\section{Financial support and sponsorship}

The authors would like to thank Directorate of Research and Community Services of Directorate General of Research and Development Strengthening from Ministry of Research, Technology and Higher Education of the 
Republic of Indonesia for the grant funding provided for this research.

\section{Conflicts of interest}

There are no conflicts of interest.

\section{Authors contributions}

- Muhammad Luthfi: Study conception, study design, intelectual content, literature research, data acquisition, data analysis, manuscript review, guarantor.

- Aqsa Sjuhada Oki: Study concept, clinical studies, experimental studies

- Yuliati: Study concept, clinical studies, experimental studies

- Agung Sosiawan: Data analysis, manuscript review

- Retno Indrawati: data interpretation, Statistical analysis, manuscript preparation, manuscript editing,

- Priyawan Rachmadi: Statistical analysis, manuscript preparation, manuscript editing,

- Muhaimin Rifa'i: manuscript editing, manuscript review

Ethical policy and Institutional Review board statement Ethical clearance test at Universitas Airlangga, Faculty of Dental Medicine was done with Health Research Ethical Clearance Commission number of 209/HRECC. FODM/ IX/2017

\section{Patient declaration of consent}

Before saliva sampling from children aged 4 to 6 years, parents of the sample had agreed to signed a written informed consent.

\section{Data availability statement}

Dataset can be made available after embargo period due to commercial restrictions

\section{RefERENCES}

1. Feldens CA, Giugliani ER, Duncan BB, Drachler Mde L, Vítolo MR. Long-term effectiveness of a nutritional program in reducing early childhood caries: A randomized trial. Community Dent Oral Epidemiol 2010;38:324-32.
2. Parisotto TM, Steiner-Oliveira C, Silva CM, Rodrigues LK, Nobredos-Santos M. Early childhood caries and mutans Streptococci: A systematic review. Oral Health Prev Dent 2010;8:59-70.

3. Iwasaki A, Medzhitov R. Control of adaptive immunity by the innate immune system. Nat Immunol 2015;16:343-53.

4. Schenten D, Medzhitov R. The control of adaptive immune responses by the innate immune system. Adv Immunol 2011;109:87-124.

5. Oft M. IL-10: Master switch from tumor-promoting inflammation to antitumor immunity. Cancer Immunol Res 2014;2: 194-9.

6. Smith AM, Qualls JE, O'Brien K, Balouzian L, Johnson PF, SchultzCherry $\mathrm{S}$, et al. A distal enhancer in Il12b is the target of transcriptional repression by the STAT3 pathway and requires the basic leucine zipper (B-ZIP) protein NFIL3. J Biol Chem 2011;286:23582-90.

7. Mosser DM, Zhang X. Interleukin-10: New perspectives on an old cytokine. Immunol Rev 2008;226:205-18.

8. Sabat R, Grütz G, Warszawska K, Kirsch S, Witte E, Wolk K, et al. Biology of interleukin-10. Cytokine Growth Factor Rev 2010;21:331-44.

9. Trigg TE, Wright PJ, Armour AF, Williamson PE, Junaidi A, Martin GB, et al. Use of a GnRH analogue implant to produce reversible long-term suppression of reproductive function in male and female domestic dogs. J Reprod Fertil Suppl 2001;57:255-61.

10. Luthfi M, Setijanto D, Rahardjo MB, Indrawati R, Rachmadi P, Ruth MSMA, et al. Correlation between human neutrophil peptide 1-3 secretion and azurophilic granule (CD63) expression in early childhood caries. Dent Res J (Isfahan) 2019;16:81-6.

11. Luthfi M, Indrawati R, Arundina I, Dachlan YP. Correlation of amount of Streptococcus mutans (S. mutans) and expression rate of interleukin 8 (IL-8) in severe early childhood caries. Maj Ked Gi Ind 2015;1:142-8.

12. Kumar H, Kawai T, Akira S. Pathogen recognition by the innate immune system. Int Rev Immunol 2011;30:16-34.

13. Veerayutthwilai O, Byers MR, Pham T-TT, Darveau RP, Dale BA. Differential regulation of immune responses by odontoblasts. Oral Microbiol Immunol 2007;22:5-13.

14. Turner MD, Nedjai B, Hurst T, Pennington DJ. Cytokines and chemokines: At the crossroads of cell signalling and inflammatory disease. Biochim Biophys Acta 2014;1843:2563-82.

15. Luthfi M, Oki AS, Indrawati R, Latuamury NS. Analysis of lymphocyte cell proliferation and IFN- $\gamma$ expression in saliva of severe early childhood caries and caries-free in Surabaya. Malays J Med Health Sci 2019;15:8-10.

16. Zens KD, Farber DL. Memory CD4 T cells in influenza, in influenza pathogenesis and control-Volume II. Curr Top Microbiol Immunol 2015;386:399-421.

17. Amarante-Mendes GP, Adjemian S, Branco LM, Zanetti LC, Weinlick R, Bortoluci KR. Pattern recognition receptors and the host cell death molecular machinery. Front Immunol 2018;9:2379.

18. Cronkite DA, Strutt TM. The regulation of inflammation by innate and adaptive lymphocytes. J Immunol Res 2018;2018:1467538.

19. Luckheeram RV, Zhou R, Verma AD, Xia B. CD4(+)T cells: Differentiation and functions. Clin Dev Immunol 2012;2012:925135. 